\title{
Norrie's disease: a prospective study of development
}

\author{
H M GOOOYEAR, P M SONKSEN, AND H McCONACHIE
}

Department of Developmental Paediatrics, The Wolfson Centre, Hospital for Sick Children, London

SUMmARY Developmental progress, hearing, and dysmorphic features were monitored prospectively in eight babies with Norrie's disease (an X linked form of congenital blindness believed to be associated with mental retardation, regression, sensorineural deafness, and dysmorphic features) and in six congenitally blind peers during their preschool years. No evidence of sensorineural deafness or dysmorphology was found in the group with Norrie's disease. No significant difference in the rate of developmental progress occurred between the two groups. All 14 children showed continuing developmental progress and in 10 this was at a normal or superior rate. Two cases and two controls showed slowing in their rate of progress; in both groups a suboptimal developmental climate had prevailed and may have been contributory.

The emphasis on serious and progressive associated disabilities in past reports has led to considerable distress for families of children with this disease. Our study suggests that these anxieties may often be illfounded. Parental depression constrains development, particularly when a baby is blind. More optimistic counselling with developmental guidance is recommended for children who are not overtly retarded in infancy until the long term developmental perspective of this disease is further clarified.

Norrie's disease is an $\mathrm{X}$ linked recessive condition of bilateral ocular malformation and blindness. Gordon Norrie (1927) identified nine Danish boys with 'atrophia oculi congenita'. ${ }^{1}$ The eye looked as 'if it had decayed after a very serious process of inflammation'. In 1961 Andersen and Warburg proposed these cases of congenital bilateral pseudotumour of the retina should be named Norrie's disease. ${ }^{2}$

The initial ocular manifestation of Norrie's disease is a grey or greyish yellow tumour like mass (pseudotumour) behind both lenses. During the first few months of life, the lenses develop cataracts and the corneas progressively opaque. Ocular pathology includes haemorrhage, vitreous opacities, glaucoma, iris atrophy, and synechiae. Phthisis bulbi is present by the end of the first decade.

Blindness is usually total by the end of the neonatal period. A few children have preservation of light perception in the first few years. Warburg postulated that blindness in Norrie's disease is due to a developmental dysplasia of the retina, which leads to total retinal detachment and proliferation of retinal vessels. ${ }^{3}$ The detached retina is seen behind the lens as a white vascular mass.

Family histories, when present, have suggested X linked inheritance. ${ }^{24}$ Diagnostic difficulty arises in the absence of a family history as the retinal dysplasia is not specific for Norrie's disease. Recent genetic advances are likely to help with diagnosis in the future; the gene for Norrie's disease (NDP) is thought to be closely linked on the regional map to locus DXS7 which is defined by the probe L1.28. Deletion of locus DXS7 has been reported in some recent cases of Norrie's disease. ${ }^{6} 7 \mathrm{~A}$ mother must be heterozygous for the $\mathrm{L} 1.28$ restriction fragment length polymorphism for the probe to be informative.

Sensorineural deafness has been reported in several studies of Norrie's disease. ${ }^{8-11}$ Warburg found deafness in approximately a third of cases. ${ }^{3}$ In her 1977 study, she proposed that hearing loss was progressive and appeared in early or middle childhood. ${ }^{12}$ Deafness has been reported as early as 4 months of age. ${ }^{13}$

A characteristic Norrie's disease facies was described by Donnai et $\mathrm{al}^{7}$ : with fine features, narrow nasal bridge, hypotelorism, flattened malar region, thin upper lip, and large ears. Microcephaly, cryptorchidism, and limb anomalies have also been described. ${ }^{911}$ Clinicians have increasingly used evidence of deafness and dysmorphology as confirmatory criteria for diagnosis of Norrie's 
Table 1 Medical, social, and family background of children with Norrie's disease (a-h) and controls (A-F)

\begin{tabular}{|c|c|c|c|c|c|c|c|}
\hline Case & Pregnancy and delivery & $\begin{array}{l}\text { Gestation } \\
\text { (weeks) }\end{array}$ & $\begin{array}{l}\text { Birth } \\
\text { weight } \\
(g)\end{array}$ & Family history & Age at diagnosis & Diagnosis & $\begin{array}{l}\text { Medical and social } \\
\text { problems and dysmorphic } \\
\text { features }\end{array}$ \\
\hline $\mathbf{a}$ & $\begin{array}{l}\text { Normal pregnancy, } \\
\text { caesarean section for } \\
\text { transverse lie }\end{array}$ & 41 & 3300 & & $\begin{array}{l}2 \text { days } \\
10 \text { wecks }\end{array}$ & $\begin{array}{l}\text { Congenital } \\
\text { buphthalmos, } \\
\text { Norrie's disease }\end{array}$ & $\left\{\begin{array}{l}\text { Intermittent conductive } \\
\text { hearing 'loss. Parental } \\
\text { separation and divorce } \\
1985-7\end{array}\right.$ \\
\hline b & $\begin{array}{l}\text { Normal pregnancy, forceps } \\
\text { delivery for failure to } \\
\text { progress }\end{array}$ & 41 & 3000 & Brother of case a & 1 day & Norrie's disease & Social factors as above \\
\hline c & $\begin{array}{l}\text { Threatened miscarriage at } \\
12 \text { weeks treated with } \\
\text { progestogens, forceps } \\
\text { delivery }\end{array}$ & 40 & 3320 & & 2 days & $\begin{array}{l}\text { Congenital } \\
\text { buphthalmos }\end{array}$ & \\
\hline d & $\begin{array}{l}\text { delivery } \\
\text { Normal pregnancy, normal } \\
\text { delivery }\end{array}$ & 40 & 3000 & Brother of case $\mathrm{c}$ & $\begin{array}{l}8 \text { weeks } \\
1 \text { day }\end{array}$ & $\begin{array}{l}\text { Norrie's disease } \\
\text { Norrie's disease }\end{array}$ & \\
\hline e & $\begin{array}{l}\text { Pre-eclampsia, normal } \\
\text { delivery }\end{array}$ & 40 & 3400 & $\begin{array}{l}\text { Parents first } \\
\text { cousins, two great } \\
\text { uncles blind }\end{array}$ & 8 weeks $^{*}$ & Norrie's disease & $\begin{array}{l}\text { Severe eczema and } \\
\text { asthma at } 18 \text { months, } \\
\text { many hospital admissions }\end{array}$ \\
\hline f & $\begin{array}{l}\text { Normal pregnancy, normal } \\
\text { delivery }\end{array}$ & 40 & 4500 & & 6 weeks* & Norrie's disease & \\
\hline g & $\begin{array}{l}\text { Normal pregnancy, normal } \\
\text { delivery }\end{array}$ & 40 & 2900 & & $\begin{array}{l}1 \text { day (white } \\
\text { mass right eye) }\end{array}$ & Norrie's discase & \\
\hline $\mathbf{h}$ & $\begin{array}{l}\text { Normal pregnancy, normal } \\
\text { delivery }\end{array}$ & 39 & 2600 & & 6 weeks* $^{*}$ & Norrie's disease & \\
\hline A & $\begin{array}{l}\text { Threatened miscarriage at } \\
12 \text { weeks, normal delivery }\end{array}$ & 40 & 3000 & & 1 day & Anophthalmos & $\begin{array}{l}\text { Hospital admissions for } \\
\text { wheezy bronchitis }\end{array}$ \\
\hline B & $\begin{array}{l}\text { Flu-like illness at } 24 \text { weeks, } \\
\text { normal delivery }\end{array}$ & 40 & 3000 & & 6 months* & $\begin{array}{l}\text { Hypoplastic } \\
\text { optic discs, } \\
\text { retinal aplasia }\end{array}$ & $\begin{array}{l}\text { Severe social deprivation } \\
\text { from } 1.5 \text { years; taken } \\
\text { into foster care age } \\
2.5 \text { years }\end{array}$ \\
\hline $\mathrm{C}$ & $\begin{array}{l}\text { Normal pregnancy, normal } \\
\text { delivery }\end{array}$ & 40 & 2700 & & 1 day & Anophthalmos & $\begin{array}{l}\text { Jaundice, given } \\
\text { phototherapy in 1st } \\
\text { week of life }\end{array}$ \\
\hline D & $\begin{array}{l}\text { Normal pregnancy, } \\
\text { caesarean section for fetal } \\
\text { distress }\end{array}$ & 41 & 3460 & Parents first cousins & 1 day & Anophthalmos & $\begin{array}{l}\text { Pyloric stenosis at } \\
3 \text { weeks. Absent left } \\
\text { index fingernail, } \\
\text { widely spaced toes and } \\
\text { nipples }\end{array}$ \\
\hline $\mathbf{E}$ & $\begin{array}{l}\text { Bleeding due to placenta } \\
\text { praevia, caesarean section }\end{array}$ & 38 & 2950 & Parents first cousins & 1 day & Anophthalmos & $\begin{array}{l}\text { Bilateral syndactyly } \\
\text { second and third toes, } \\
\text { absent fifth toes; } \\
\text { preauricular skin tag } \\
\text { left ear }\end{array}$ \\
\hline $\mathbf{F}$ & $\begin{array}{l}\text { Small bleed at } 12 \text { weeks, } \\
\text { normal delivery }\end{array}$ & 40 & 3300 & & 3 months & $\begin{array}{l}\text { Hypoplastic optic } \\
\text { discs }\end{array}$ & $\begin{array}{l}\text { Jaundice, given } \\
\text { phototherapy in 1st } \\
\text { week of life. } \\
\text { Glucose-6-phosphate } \\
\text { dehydrogenase } \\
\text { deficiency }\end{array}$ \\
\hline
\end{tabular}

*Not fixing or following.

disease. ${ }^{71011}$ Our clinical experience has led us to doubt the diagnostic status of these signs.

Mental retardation has been described in Norrie's disease. Warburg's study in 1966 is the main source of developmental knowledge on Norrie's disease. She looked at 35 cases consisting of children in institutions for the blind and cases found from retrospective data. ${ }^{3}$ Sources included The Index of Diagnoses of Ocular Diseases in Mentally Deficient Patients in Denmark and a survey of blind adults in homes for the mentally deficient. Forty five per cent
(16/35) were born before 1900 and documentation of early milestones and development is scanty. Warburg described normal development during the first two years of life in all boys. ${ }^{314}$ Subsequent progress was then distributed equally between three categories. Development continued normally into adult life in approximately one third of cases. Slowing of development was noted in another third after the age of 2 years; they presented as moderately slow learners in their early school years but continued to lose skills in teenage and adult life. The 
remaining third regressed rapidly after the age of 2 years losing their previous skills. Our clinical experience led us to question the developmental perspective outlined by Warburg.

This study was undertaken to review early developmental patterns, sensorineural deafness, and dysmorphic features in Norrie's disease.

\section{Subjects and methods}

The diagnostic criteria for Norrie's disease applied in this study are a clinically compatible retinal dysplasia and total blindness present in the first few months of life coupled with negative history and investigation for alternative aetiological factors.

Development has been prospectively monitored in children with Norrie's disease and compared with the development of a control group blind from other causes. The study and control groups were derived from 345 children referred to the developmental vision clinic at the Wolfson Centre from 1975-86. Children referred to this specialised clinic are all severely visually impaired and often multiply disabled. Those with any residual sight after the first few months of life or a history of prematurity, congenital infection, 'brain damaging' events or abnormality on computed tomography were excluded. Eight cases fulfilled the above criteria for Norrie's disease. Six totally blind children fulfilled the criteria for the control group.

Assessments were performed at regular intervals by a psychologist and a paediatrician for children in both groups. The following details were recorded for each case: family history, physical features, and hearing and growth indices. Development was assessed on the Reynell-Zinkin developmental scales of young visually handicapped children, using the sensorimotor understanding and verbal comprehension subscales. Scores were compared with age equivalents for blind children derived from the standardisation sample of Reynell. ${ }^{15}$ The progress of children after they reached the age of 5 years was monitored using the British ability scales, sighted norms. ${ }^{16}$ The four subscales thought to be least affected by visual impairment-that is, verbaltactile matching, recall of digits, verbal fluency, and similarities-were used. Hearing assessments were performed by distraction technique, discrimination of speech, free field audiometry, or audiometry with headphones as developmentally appropriate.

\section{Results}

There was no history of neonatal difficulties or medical history relevant to blindness in either group (table 1). A positive family history was obtained in five of the children with Norrie's disease: the parents of one child (case e) were first cousins and, therefore, had in common two great uncles who were blind but of normal development, and cases a and $b$ and $c$ and $d$ were sibling pairs. There was no family history of blindness in the control group. Two sets of control parents were first cousins (of cases D and E) but blindness did not feature in any family. Dysmorphic features were noted in two of the control children (cases D and E) but none of the study group.

Hearing loss was detected in one child with Norrie's disease (case a) and in none of the controls. The loss in this case was conductive and had been intermittent, associated with flat impedance curves and dull eardrums on inspection. At $6 \cdot 8$ years of age, hearing was normal on the right and a $30 \mathrm{~dB}$ conductive loss was present on the left.

The developmental progress of study and control groups is shown in table 2 and figs $1-4$. There was no

Table 2 Developmental progress assessed on Reynell-Zinkin developmental scales

\begin{tabular}{|c|c|c|c|c|c|c|}
\hline \multirow[b]{2}{*}{$\begin{array}{l}\text { Age } \\
\text { band* }\end{array}$} & \multirow[b]{2}{*}{ Group } & \multicolumn{2}{|c|}{ Sensormotor understanding } & \multicolumn{2}{|c|}{ Verbal comprehension } & \multirow[b]{2}{*}{ Total } \\
\hline & & $\geqslant$ Blind norm & $<$ Blind norm & $\geqslant$ Blind norm & $<$ Blind norm & \\
\hline \multirow[t]{2}{*}{1} & Norrie's & 7 & 1 & 6 & 2 & 8 \\
\hline & Control & 4 & 1 & 4 & 1 & 5 \\
\hline \multirow[t]{2}{*}{2} & Norric's & 6 & 2 & 6 & 2 & 8 \\
\hline & Control & 3 & 3 & 2 & 4 & 6 \\
\hline \multirow[t]{2}{*}{3} & Norrie's & 5 & 3 & 5 & 3 & 8 \\
\hline & Control & 3 & 3 & 1 & 5 & 6 \\
\hline \multirow[t]{2}{*}{4} & Norrie's & 5 & 2 & 5 & 2 & 7 \\
\hline & Control & 2 & 1 & 2 & 1 & 3 \\
\hline 5 & Norrie's & 4 & 2 & 4 & 2 & 6 \\
\hline
\end{tabular}

${ }^{*}$ Assessment closest to date of $1 \mathrm{st}, 2 \mathrm{nd}, 3 \mathrm{rd}, 4 \mathrm{th}$, and 5 th birthdays. 


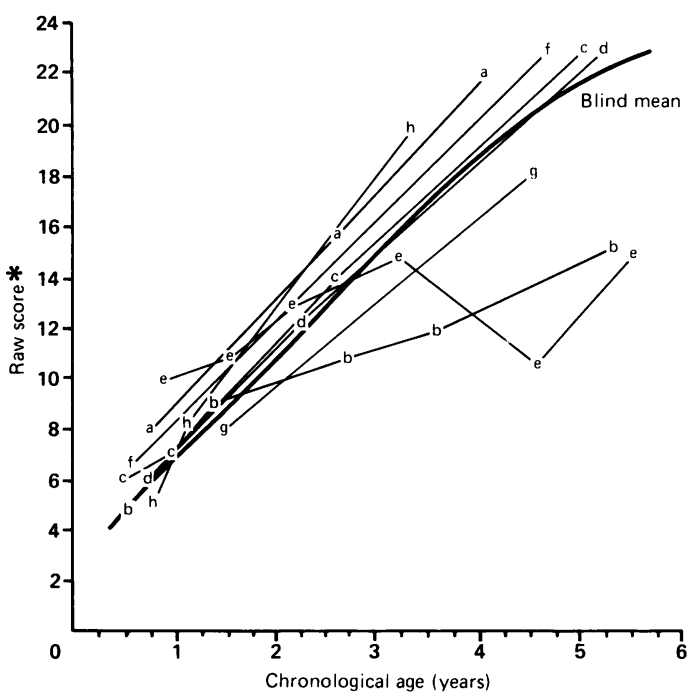

Fig 1 Sensorimotor understanding in Norrie's disease. ${ }^{*}$ Each item on this subscale of the Reynell-Zinkin developmental scale scores 1 ; the Raw score indicates the number of items achieved.

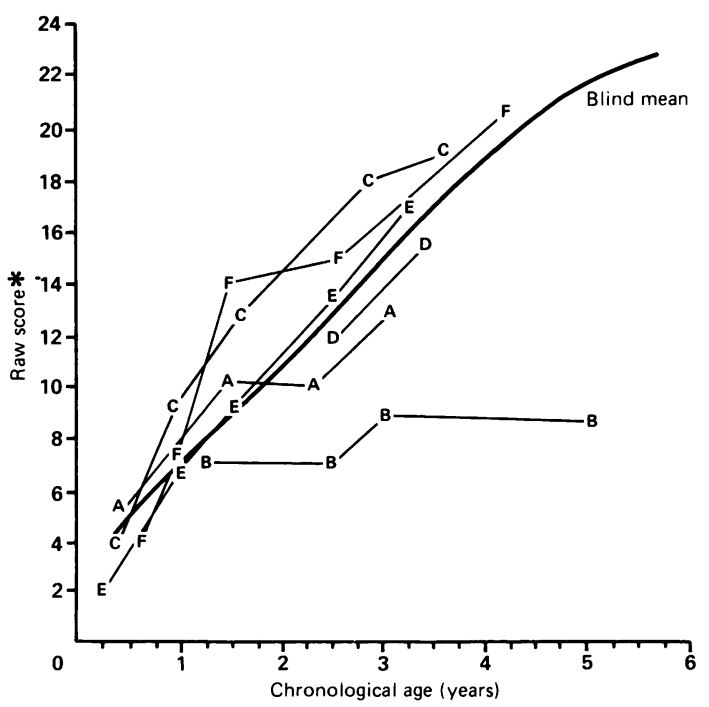

Fig 2 Sensorimotor understanding in controls. ${ }^{*}$ Each item on this subscale of the Reynell-Zinkin developmental scale scores 1; the Raw score indicates the number of items achieved.

significant difference in development between the two groups at any age (Fisher's test of exact probability). The only finding to approach significance was verbal comprehension at 3 years of age, where the difference was in the opposite direction to

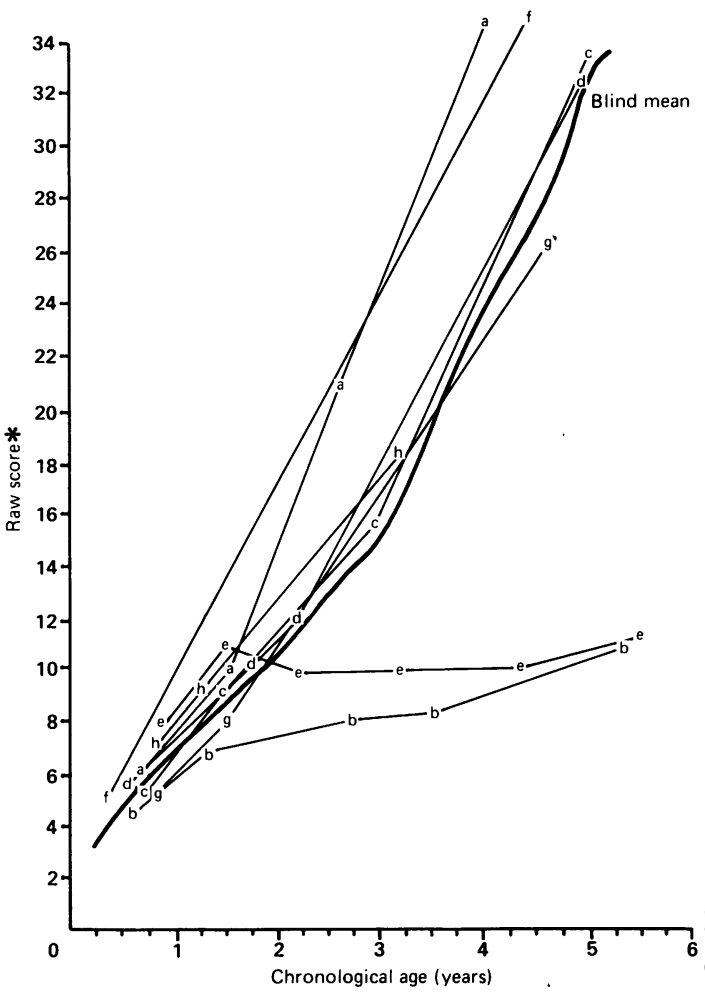

Fig 3 Verbal comprehension in Norrie's disease. *Each item on this subscale of the Reynell-Zinkin developmental scale scores 1; the Raw score indicates the number of items achieved.

that expected from Warburg's retrospective data. Six children with Norrie's disease $(75 \%)$ and four controls $(66 \%)$ showed steady rates of development. In eight children (from both groups) this was at or above the blind 'norm'; in one child with Norrie's disease, and one control (cases $g$ and D) this was just below the blind 'norm'. Four of the children with Norrie's disease (cases a, c, d, and f), who were recently reassessed on the British ability scales, scored in the above average range and two (cases a and $f$ ) in the superior range of norms for sighted children. Four children, equally divided between study and control groups (cases b, e, A, B), showed a plateauing in their developmental skills around the age of 2 years. At last assessment they would be described as mentally retarded. In both groups, regression or poor progress seemed to be associated with illness requiring frequent hospital admissions or social deprivation (table 2). All these children showed evidence of continuing development, although at a slower rate than normal. 


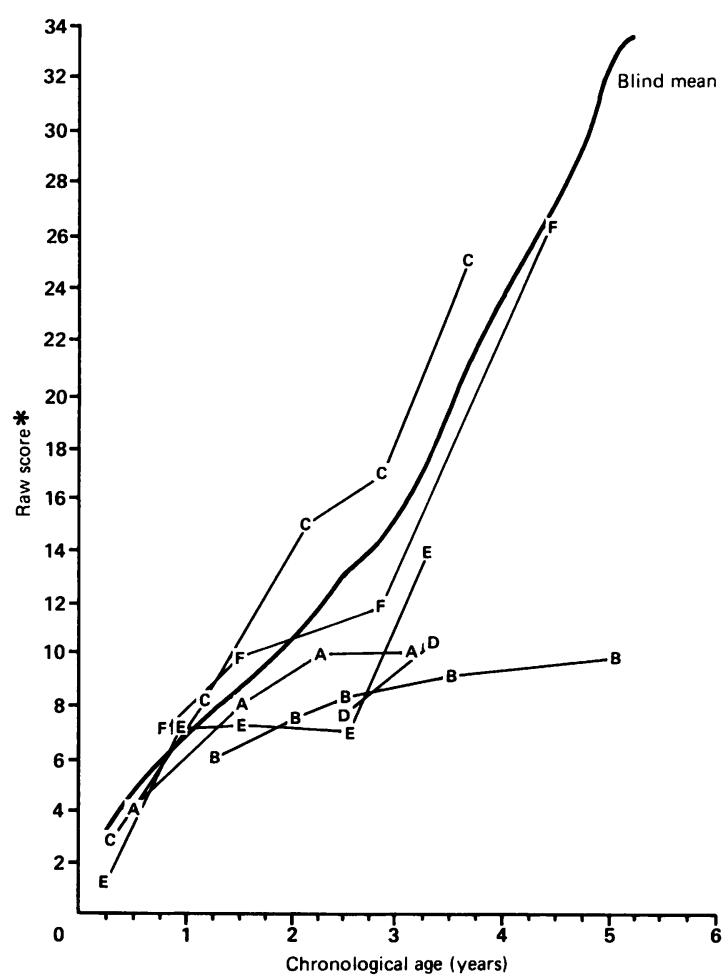

Fig 4 Verbal comprehension in controls. * Each item on this subscale of the Reynell-Zinkin developmental scale score 1; the Raw score indicates the number of items achieved.

\section{Discussion}

A conductive hearing loss was present in one child with Norrie's disease. There was no evidence of sensorineural hearing loss in the first five years among our sample of children. Our study does not confirm reports of early onset of sensorineural hearing loss. A developmentally age appropriate test was selected for each child in our study, thereby overcoming Warburg's difficulty in obtaining reliable hearing assessments in cases who were mentally retarded or unable to speak. Most hearing losses were identified in the third decade of life in Warburg's series so we propose to continue to monitor hearing prospectively in our group.

The characteristic facies described by Donnai et $a l^{p}$ and other physical features such as cryptorchidism, microcephaly, and limb anomalies were absent in our series. Warburg did not discuss dysmorphic features in her description of Norrie's disease. When such features are associated with
Norrie's type retinal dysplasia the explanation may lie in the width of the faulty gene segment of the $\mathrm{X}$ chromosome in the individual case.

Genetic considerations make precise diagnosis important. A female carrier of the Norrie's disease gene has a $50 \%$ chance of having an affected child if the fetus is male. Other ocular conditions that require to be differentiated are bilateral retinoblastoma, retinoschisis, falciform detachment of the retina, retrolental fibroplasia, and syndromes with retinal dysplasia. ${ }^{17}$ Serial ocular examinations by a specialist during the early weeks of life facilitate the differential diagnostic process. Our findings suggest that diagnostic criteria should be primarily visual and ocular and not include the range of associated features such as mental retardation, dysmorphology, and hearing impairment. Total blindness by the age of a few weeks plus ocular signs compatible with a Norrie's retinal dysplasia together with exclusion of the other conditions mentioned above should at present be the essential criteria. A positive family history is strong supportive evidence but not essential. ${ }^{17}$ The recent identification of the gene locus for Norrie's disease and the discovery of a suitable probe have made prenatal diagnosis possible. ${ }^{6}$ Extension of the research is likely to clarify whether adjacent sites are abnormal in those cases with associated features and whether in such families they tend to breed true.

In the current study, prospective monitoring of early development in Norrie's disease has shown a different perspective to that described by Warburg. Most of these children are of normal ability when compared with their blind peers. Children with Norrie's disease were not more likely to be mentally retarded than controls. The two children who showed superior mentality at the age of over 5 years when assessed using the British ability scales (sighted norms) emphasise the existence of such a subgroup. Warburg reported that a third of children with Norrie's disease show regression of development during the preschool years. A quarter of our sample (cases b and e) showed plateauing followed by slow progress rather than further regression. Some of the difference in developmental perspective of the two series may reflect a sampling bias; the population of Warburg's series was drawn mainly from institutions for the blind and the data was mainly retrospective. Blind children are particularly susceptible to developmental stasis or regression if the developmental climate is suboptimal as a consequence of emotional deprivation or admission to hospital. ${ }^{18}$ Such a climate prevailed in both study and control group children in whom such a pattern was seen.

The possibility that their son and future sons may 
not only be blind, but could develop further impairments such as mental retardation or deafness, greatly increases parental anxiety and distress. This concern will be mirrored in young couples related to the mother. ${ }^{19}$ Warburg's 1966 review and recent case reports understate the cases who remain of average or superior intelligence throughout life, ${ }^{7913}$ and thus heighten rather than alleviate parental and professional despair about Norrie's disease. Despair and depression can reduce a mother's ability to interact and promote her baby's development-a developmental disaster for a blind baby. ${ }^{20}$ Until further studies show the true long term perspective in this disease a more optimistic approach, coupled with a programme to promote development, is recommended as the wisest developmental counsel in cases who do not show overt retardation in the early months.

\section{References}

1 Norrie G. Causes of blindness in children. Acta Ophthalmol (Copenh) 1927;5:357-86.

2 Andersen SRM Warburg M. Norrie's disease. Arch Ophthalmol 1961;66:614-8.

3 Warburg M. Norrie's disease: a congenital progressive occuloacoustico-cerebral degeneration. Acta Ophthalmol [Suppl] (Copenh) 1966;89:1-147.

4 Warburg M. Norrie's disease (atrofia bulborum hereditaria). Acta Ophthalmol (Copenh) 1963;41:134-46.

5 Bleeker-Wagemakers LM, Friedrich U, Gal A, Wienker TF, Warburg M, Ropers HH. Close linkage between Norrie's disease, a cloned DNA sequence from the proximal short arm and the centromere of the $\mathrm{X}$ chromosome. Hum Genet 1985;71:211-4.

6 De la Chapelle A, Sankila EM, Lindlof M, Aula P, Norio R.
Norrie's disease caused by a gene deletion allowing carrier detection and prenatal diagnosis. Clin Genet 1985;28:317-20.

7 Donnai D. Mountford RC, Read AP. Norrie's disease resulting from a gene deletion: clinical features and DNA studies. $J$ Med Genet 1988;25:73-8.

${ }^{8}$ Liberfarb RM, Eavey RD, De long GR, Albert DM, Dieckert JP, Hirose T. Norrie's disease: a study of two families. Ophthalmology 1985;92:1445-51.

${ }^{9}$ Holmes LB. Norrie's disease. An X-linked syndrome of retinal malformation, mental retardation and deafness. $J$ Pediatr 1971;89:89-92.

10 Phillips CI, Newton M. Duvall J. Holloway S, Levy AM. Probable Norrie's disease due to mutation. Br J Ophthalmol 1986;70:305-13.

11 Moreira-Filho CA, Neustein I. A presumptive new variant of Norrie's disease. J Med Genet 1979:16:125-8.

12 Parving A, Warburg M. Audiological findings in Norrie's disease. Audiology 1977;16:124-31.

13 Blodi FC, Hunter WS. Norrie's disease in North America. Doc Ophthalmol 1969:26:434-50.

14 Warburg M. Norrie's disease. J Ment Defic Res 1968;12:247-51.

15 Reynell J. Manual for the Reynell-Zinkin scales. London: National Foundation of Education Research, 1979.

16 Elliott CD, Murray DJ, Pearson LS. British ability scales. Windsor: National Foundation of Educational ResearchNelson, 1978.

17 Warburg M. Norrie's disease - differential diagnosis and treatment. Acta Ophthalmol (Copenh) 1975;53:217-36.

${ }^{18}$ Sonksen PM. Vision and early development. In: Wybar K, Taylor D, eds. Pediatric ophthalmology. New York: Marcel Dekker, 1983:85-95.

19 Harendra de Silva DG, De Silva DBK. Norrie's disease in an Asian family. $\mathrm{Br} J$ Ophthalmol 1988;72:62-4.

${ }^{20}$ Sonksen PM. Constraints upon parenting: experience of a paediatrician. Child Care Health Dev 1989;15: No 1.

Correspondence to Dr PM Sonksen. Department of Developmental Paediatrics. The Wolfson Centre, Hospital for Sick Children, Great Ormond Street, London WC1N 2AP.

Accepted 9 March 1989 